\title{
Geographic shifts in cross border entertainment: The lossofcompetitiveness in Ciudad Juarez, Mexico
}

\author{
Transformações na geografia do turismo fronteiriço: \\ A perda de competitividade em Ciudad Juárez, México
}

\section{Cambios en la geografia del turismo fronterizo: La pérdida de competitividad en Ciudad Juárez, México}

Francisco Javier Llera Pacheco

fllneek@gmail.com

Universidad Autonoma De Ciudad Juarez

AngelesLopez-Norez

anlopez@uacj.mx

Universidad Autonoma De Ciudad Juarez

Fany Thelma Solis

fsolis@uacj.mx

Universidad Autonoma De Ciudad Juarez

Elizabeth Bautista Flores

ebautis@uacj.mx

Universidad Autonoma De Ciudad Juarez

Julian Alvarez

jalvarez@uacj.mx

Universidad Autonoma De Ciudad Juarez

\begin{abstract}
This study traces how entertainment patterns have changed among residents in the Mexican border city of Ciudad Juarez, Mexico, as a result of crime and public insecurity. The document is based on empirical research conducted among College students in Ciudad Juarez. Since most of the entertainment activities in this region are addressed to young people, the research group decided to take College Students from the largest public university in the city as the main focus for data collection because they provide sufficient representativeness of the young population living in the different geographic locations in the city.Research findings suggest that as a result of crime and public insecurity, there exists a tendency among the young population to cross into the USA in order to search for entertainment. Nevertheless, crime and insecurity have not modified the entertainment preferences of foreign visitors. Data results found by this study also suggest that the two preferred entertainment activities in Ciudad Juarez are attending to restaurants and also to bars. Such results imply that the levels of education in the city are not a factor that modifies the search of entertainment itself, and there exists a very simple entertainment culture among local population. Further research should be dedicated to find out in what degree such dominant preferences for
\end{abstract}


eating and drinking have limited the development of other cultural activities and the diversification of the entertainment sector along the Northern Mexican Border cities.

Keywords: Entertaiment. Mexican border. Deliquency. Collegestudents.

Resumo: Este estudoexamina dequeforma os padrões de entretenimento dos moradores da cidade fronteiriça mexicana de Ciudad Juarez mudaram seu comportamento como resultado da delinquência e da insegurança pública. O documento se baseia em pesquisa empírica realizada entre estudantes universitários de Ciudad Juarez. Dado que a maior parte do entretenimento na região está associada à juventude, decidiu-se coletar dados tendo como foco estudantes da maior universidade da cidade. Embora estes apenas caracterizem um segmento da população, entre os diversos grupos que a habitam, eles foram escolhidos por tratar-se, social e economicamente, de uma amostra representativa. As descobertas sugerem que, como resultado do crime e da insegurança, há uma tendência entre os jovens de atravessar para os Estados Unidos (EUA) em busca de entretenimento. Da mesma forma que em Ciudad Juarez, as duas atividades de entretenimento preferidas são os restaurantes e bares, envolvendo padrões de entretenimento muito simples. Isso sugere que a diferença de nível educacional não é fator que modifica a busca de entretenimento e, portanto, tem-se uma diversificação pequena. Estudos futuros deverão aprofundar a análise sobre até que ponto as preferências de entretenimentos relacionados à alimentação e bebida limitam a diversificação deste setor nas cidades fronteiriças do norte do México.

Palavras-chave: Entretenimento. Fronteira mexicana. Delinquência. Estudantes universitários.

Resumen: Este estudio examina cómo los patrones de entretenimiento de los residentes en la ciudad fronteriza mexicana de Ciudad Juárez, México, han cambiado como resultado de la delincuencia e inseguridad pública. El documento se basa en la investigación empírica realizada entre estudiantes universitarios en Ciudad Juárez. Dado que la mayoría de las actividades de entretenimiento en esta región están relacionadas con los jóvenes, el grupo de investigación decidió recopilar los datos enfocándose en estudiantes de la universidad más grande en la ciudad, que aunque sólo caracterizan un segmento de población entre los varios grupos que la habitan, fueron elegidos debido a que social y económicamente, son una muestra representativa de su población joven. Los hallazgos sugieren que como resultado de la delincuencia e inseguridad, existe tendencia entre la población joven a cruzar hacia los Estados Unidos (EUA)en la búsqueda de entretenimiento y que a pesar de la delincuencia e inseguridad, las preferencias de entretenimiento de los visitantes extranjeros no se han modificado. De igual forma se encontró que las dos actividades preferidas de entretenimiento en Ciudad Juárez son acudir a restaurantes y bares, lo que implica patrones muy simples de entretenimiento y sugiere que las diferencias en el nivel de educación no son un factor que modifique la búsqueda de entretenimiento, por lo cual se tiene una diversificación pobre.Futuros estudios deberán enfocarse al análisis del nivel en que las preferencias por entretenimiento vinculadas a la comida y bebida, limitan la diversificación de este sector de actividad en ciudades de la frontera norte mexicana.

Palabras clave: Entretenimiento. Frontera mexicana. Delincuencia. Estudiantes universitarios. 


\section{INTRODUCTION}

The purpose of this study is to identify how entertainment patterns have changed among local population in Ciudad Juarez, Mexico during the last 5 years as a result of crime and social unrest experienced by the city. The particular social crisis that is lived in this border city has reduced the entertainment activity to the minimum and has produced an exile of Mexican restaurants, bars and other entertainment activities inside the USA. In order to have a better understanding of such phenomena, and for purpose of organization, this article encompasses four sections. First, the document explains the methodological design followed by the research team to conduct this research study. Second, the essay provides a general overview about the historical development of entertainment activities in the Mexican border cities with the United States. Third, to illustrate how crime rates have modified the traditional patterns of the local population on searching for entertainment in the Mexican border city of Ciudad Juarez, this article presents data results about entertainment patterns among young population. Finally, the last section is addressed to conclusions and perspectives.

\section{METHODOLOGIES}

Data collection for this research was conducted between August and November 2010. A survey with 5 close ended questions and 6 multiple answers was prepared to obtain uniform data from 408 College Students at the Universidad Autónoma de Ciudad Juarez. Since most of the entertainment activities in this region are addressed to young people, the research group decided to take College Students from the largest public university in the city as the main focus for data collection. College students characterize only one group among the several groups of young people living in the Mexican border city of Ciudad Juarez. Notwithstanding, College students from the largest local public university were chosen as sample population due to the significant social and economic representation they offer from the young population living in the different geographic locations of the city. Data results corroborate that the sample population was representative from the different geographic locations of the city and from different social and economic population groups. Perceptual analysis was used for data interpretation.

\section{ENTERTAINMENTS IN THE MEXICAN BORDER WITH THE UNITED STATES OF AMERICA (USA)}

\subsection{The USA/Mexico Border}

Territorial Borders have the potential to produce economic growth in local regions based on tourism and entertainment activities. Entertainment and leisure activities addressed to bring USA visitors into the Mexican side have been fundamental since 
the early 1900's for the economic development of the Northern Mexican border cities. Particularly, activities related to casinos, restaurants, night clubs, horse and dog racings were fundamental to enrich the local economy (ALVAREZ, 2009). Between 1910 and 1921, the Mexican Revolution constraints the local economic activity of the Mexican border cities, notwithstanding, in some border locations experiencing revolutionary conflicts such situation produced the emergence of certain type of entertainment activities that lured USA visitors interested to observer evolutionary episodes (PÉREZ, 2004). After the Mexican revolution, the Northern Mexican border cities took advantage of two external events directly related with the USA and that produced a detonation for the emergence of entertainment activities on the Mexican border side: the approval of the Alcohol Prohibition Act (Volstead Law) by the USA Congress in 1919 and the involvement of the USA in the World War II in the mid 1940's (GALLEGOS; LÓPEZ, 2004). The first event prohibited the production, importation, selling and consumption of liquor in the USA and the second event increased the allocation of USA soldiers in Military Bases established along the USA border. Both situations encouraged the emergence of bars, casinos and night clubs in the Mexican border cities producing economic growth in those towns that were benefited from the large flows of USA visitors (MARTíNEZ, 1978). From 1950 to 2000, entertainment activities promoted by the Northern Mexican border cities have been majorly based in activities related to alcohol such as bars and night clubs, to gambling such as Palenque (GONZÁLEZ DE LA VARA, 2002) and casinos and to sports such as soccer, bullfights, box and wrestling (ALVAREZ, 2009). All of them, being promoted in the different border cities without planned strategies to integrate and give coherence to the local economic development in most of these Mexican border cities. Moreover, such disassociation that is observed in the local entertainment industry of these towns might be a difficult barrier to overcome and to become competitive in time of crisis of any class (either economic or social) such as it is happening during the present time in some Northern Mexican border cities.

In Mexico, it has been estimated that the development of tourism on the Northern Mexican border region contributes with $19 \%$ of the Gross National Product (BRINGAS et al., 2004). Therefore, the economic competitiveness of the Northern Mexican border cities is based on entertainment activities and tourism. Both activities face a two-fold challenge in the present time. On the one hand, the absence of integration between public policies and types of entertainment initiatives promoted at the local scale. On the other hand, the existence of a risky social climate that negatively influences the development of innovative entertainment activities to bring, retain, and provide confidence and security to foreign and local customers. The first challenge has origins in the existence of a strong federal government which centralizes economic resources and barely encourages local economic initiatives. Both factors generate that the design of Federal Policies to lure foreign visitors to Mexico disregarded the particular characteristics of the different classes of visitors that arrive to each region of the country. As a results of this, Federal programs to promote tourism and entertainment do not benefit the local entertainment businesses since the economic incentives, if they exist, are addressed to attract a prototype of visitor that is 
not present in some localities such as the border cities in the North. In other words, it is completely different the economic impact that a foreign visitor produces inland the country than in the border cities. To illustrate, in 2003, it was estimated that for every US dollar that is spent by a foreign visitor in the Mexican border cities, US \$9.4 Dollars are spent by foreign visitors in locations that are in the interior of the country. The predominant type of foreign visitors to the Mexican border cities are low educated and low income persons presenting an average of 12 years of education and presenting an average annual income that range between US \$20,000 and 40,000 dollars. This type of visitors also look for entertainment activities that are according to their cultural background and this explains why $33 \%$ of their expenditure is done in restaurants, $19 \%$ in bars and night clubs, $17 \%$ in supermarkets, $6 \%$ in liquor and $5 \%$ in hotels (BRINGAS, 2004). The differences between the type of foreign visitor that predominates in border cities and the foreign visitor that is targeted through governmental plans produces a fragmentation between the local entertainment sector and the goals in tourism and entertainment pursued at the Federal level. Moreover, such situation leaves the impression that in Mexico there are not policies to promote tourism and entertainment and that both activities are based on spontaneous initiatives in each locality.

The second challenge for losing competitiveness in entertainment and tourism is the risky social climate that prevails in most of the Northern Mexican border cities and negatively influences the local economic development. Official data provided by governmental institutions reports a decrease of $8.7 \%$ in incoming border tourists during 2007 (BANCO DE MÉXICO, 2007; MÁRQUEZ, 2007). The main reason for such decrease is attributed to crime and to the public insecurity prevalent within the Northern Mexican Border cities.

\subsection{The Ciudad Juarez/El Paso region}

The Ciudad Juarez/El Paso region provides a true perspective of how tourism and leisure influences development. Historically, during the Mexican colonial period between 1517 and 1810, Missions ${ }^{1}$ were a key element for the development of the current border communities, where commerce and general services were more developed and populated on the nowadays Mexican side. From 1810 to 1821, Mexico declared its independence from Spain. During that time entertainment in the Mexican Northern towns were centered mainly in bull fights, religious events and patronage fairs. From 1847 to 1849, the Mexican American War brought as a consequence the divisionary line between Mexico and the United States of America (USA) and produced that trade and entertainment constituted two of the most important sources of living for the existing settlements located in the new border limits. Among those, the so called Paso del Norte region (now Ciudad Juarez /El

1 Missions were main Catholic churches and settlements established by the Spaniards Conquests to teach Catholic religion to the local Indian inhabitants. 
Paso) became the largest trading and entertainment center located in the divisionary line among the two countries (GONZÁLEZ DE LA VARA, 2002)

This situation has produced a double-fold pattern that is gravely affecting the economic stability of Ciudad Juarez, and consequently, its former economic attractiveness. The first pattern is the reduction in the number of entertainment businesses that operate within the city. It has been estimated that about $40 \%$ of restaurants and $18 \%$ of bars have closed down as a result of the absence of customers or as a result of economic extortions (300 to 3000 US Dollars per month) that make unprofitable to run a business locally (CHAPARRO, 2011; OTERO, 2010). At the same time, it is estimated that most of the entertainment businesses that have left activities in Ciudad Juarez as a result of the unsecure local environment have decided to relocate the same concept on the other side of the border where they find a better business climate and safe environment (CHAPARRO, 2011). The second pattern is related to the reduction in the demand of entertainment by local inhabitants. There exists an empirical perception on the Juarez entertainment sector that local residents are now spending in entertainment in El Paso (ELP) rather than in Ciudad Juarez. In addition, it seems that the traditional advantages of the Mexican side regarding the quality of services, the diversity on entertainment activities and the low prices of the services are now been hammered by the local crime rates and unsafe social conditions. This situation has produced the migration of the Juarez customers to El Paso entertainment businesses (OTERO, 2010). Since there is not official data or documents that corroborate such tendency, in the following part, this document presents an inference of what could be the current patterns of the local inhabitants in Ciudad Juarez searching for entertainment. Then, in the last part, this document suggests some actions that might contribute to reactivate the economic activity of the local entertainment sector.

\section{ENTERTAINMENT AND COLLEGE STUDENTS: A CASE STUDY AT THE UNIVERSIDAD AUTONOMA DE CIUDAD JUAREZ}

\subsection{Entertainment in Ciudad Juarez}

Ciudad Juarez is the oldest settlement along the current USA/Mexico border region and has been traditionally considered a place for entertainment (MARTÍNEZ, 1978). To illustrate, in 2003, this city attracted 14.8 million international visitors out of the 77 million that visited the entire border region (BRINGAS, 2004). The reason for this economic specialization has been the geographic location of the city, almost in the middle of the USA border, and the long distances to other major urban centers either from Mexico or from the USA (Map 1).

This situation fostered the development of leisure activities both for foreign visitors and for people leaving in the neighboring areas on both sides of the border. The promotion of the Border Industrial Program in the city since 1965 contributed even more to encourage the growth of entertainment activities because the majority of the local population enjoyed economic progress (TURNER, 2006). For more than 30 years, Juarez 
Map 1 - Location of the Ciudad Juarez / El Paso border region

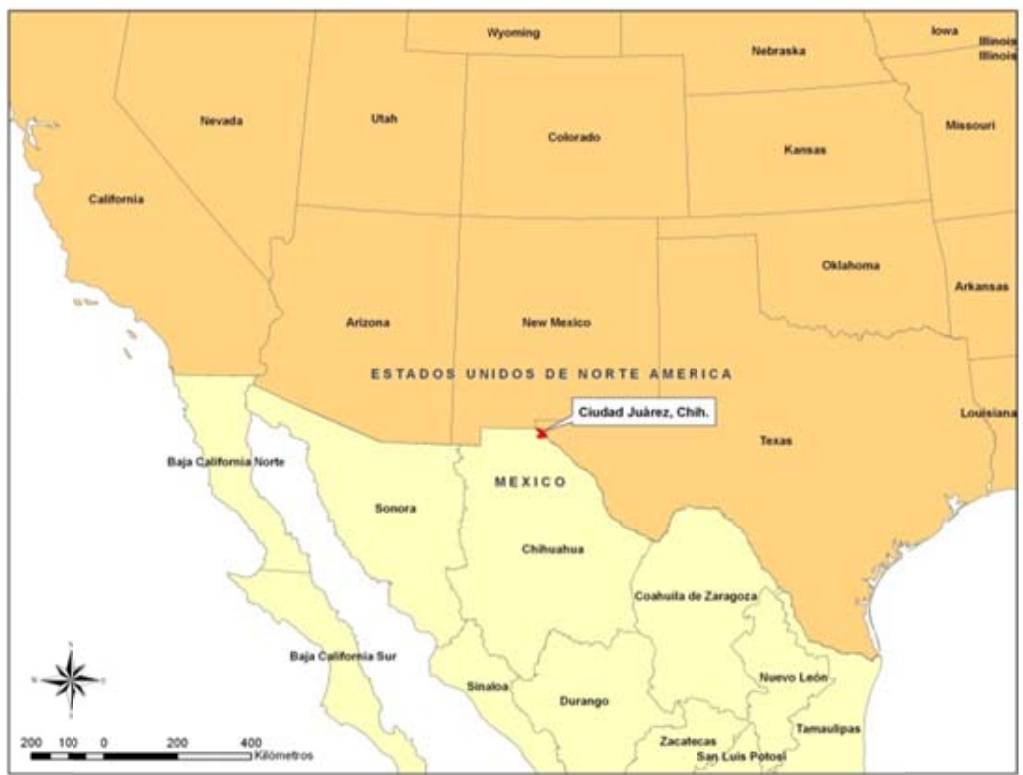

was the main center that concentrates the majority of the leisure and touristic activities in the region. Night life activities such as dancing places, restaurants, bars and even hotels were dominant in the local economy and became the second major source of employment for this locality (PEÑA, 2003). Such dynamic in Juarez accompanied by the presence in the city of one of the largest USA Consulates in the world produced the arrival of large flows of visitors for business and leisure purposes (LLERA et al., 2009).

The success of Ciudad Juarez to develop economic activities related to industry, retail, entertainment and others, was also possible due the accessible geographic location of this city from both the eastern and western areas of the USA. This factor has also benefited El Paso, Texas, which is located just one the other side of the border of Ciudad Juarez. Even though both cities have the same potential to benefit from their geographic accessibility and to take advantage of the coexistence of two cultures to bring visitors from both Mexico and the USA, they have not developed joint and common plans neither in economic development nor in tourism. The region is not taking advantage of their straightness as one unit such as it is happening in other border regions which have implemented bi-national strategies both to attract and to retain international tourism and benefit the development of the regional entertainment sector ${ }^{2}$. An example of such strategies is the One region Pass established in some of the border cities Between Canada and the USA where they jointly promote entertainment for foreign visitors independently if they arrive to one or the other side of the border (LLERA; LOPEZ, 2010). The disconnection in local economic strategies between Ciudad Juarez and El Paso has produced that during the last years both cities present an unequal behavior in terms of the economic impact that tourism brings to entertainment sector in each city. For example,

2 In this paper, entertainment sector is defined as the group of business that offer services or activities related with food, alcoholic beverages, music, dancing, culture, recreation and repose. 
entertainment consumers in the Paso del Norte $^{3}$ region College students represent the population groups that are the most active clients of such activities in Ciudad Juarez.

The total sample population considered in this study encompassed 408 College Students out of the 20,000 enrolled at the Universidad Autónoma de Ciudad Juarez in 2010. In the total sample population, 201 were male and 207 were female. In order to estimate their economic potential on entertainment they were asked about their source of income. To this regard, $49 \%$ of total population was only dedicated to study and their supply of economic resources came from their families. Another $44 \%$ of the total population was employed and obtained their supply of economic resources from it. It was unknown how $7 \%$ of the total population obtained their supply of economic resources. Research results show that $27 \%$ of the total sample population has no visa to cross into the USA and never goes to the city of El Paso (ELP) for any reason, while 54\% cross to ELP searching for entertainment. The two preferred entertainment activities carried on by College Students when they cross to ELP were attending to restaurants (34\%) and to Bars (27\%).

Data analysis portray that older College Students, 21years and older, cross more frequently the border searching for entertainment (55\%) than younger students ranging between 17 and 20 years old (45\%). On the one hand, such economic pattern observed among older College Students could be explained by their economic self-reliance or economic independency. The data collected shows that $65 \%$ of students older than 21 years old at UACJ study and work simultaneously. This situation provides to them a more comfortable economic situation to spend and to travel to ELP searching for entertainment in restaurants and bars. Notwithstanding, the gender factor plays a relevant role in such behavior. Research results show that $60 \%$ of students that cross searching for entertainment in ELP are men. This could suggest that female College Students with some type of economic independence do not spend very much in entertainment rather their expenditure might be addressed to other areas such as shopping or savings. One last factor to explain why older College Students cross more frequently the border searching for entertainment is that they have reached the age (21 years old) to drink alcohol in Bars located in ELP. In Ciudad Juarez, bars are the most benefited sector from College Students younger than 21 years old. On the other hand, it might be argued that restaurants in ELP could be the most benefited entertainment sector by the attendance of young College Students. Data shows that $71 \%$ of the total number of students ranging between 17 and 20 years old only study. As explained above, in such group of College Students there still exists an economic dependency from their families which is a common situation for the Mexican context. In Ciudad Juarez, it is a common pattern that families cross the border and attend together to ELP to consume in restaurants. This situation, together with the age restriction to drink alcohol in ELP, contributes to the benefit of the restaurant industry in ELP.

Overall, findings in this research show that there is an increasing pattern to cross the border searching for entertainment among College Students from Ciudad Juarez. Results

3 Paso del Norte is the original name assigned to the current area of Ciudad Juarez, Mexico and El Paso, Texas before the War between Mexico and the USA in 1847 that led to the fragmentation of the Mexican territory. 
in November 2010, the City Plan of El Paso estimated that about 3 million people visited this city annually to conducted tourism activities generating about $\$ 795$ million dollar a year. Notwithstanding, it is uncertain how many people and how much revenues from such activities have an impact in the Ciudad Juarez entertainment sector.

\subsection{Current Constrains for Tourism and Entertainment in Ciudad Juarez}

Tourism in Ciudad Juarez has neither been developed following a long-term vision nor a bi-national vision. Rather, it has followed short-term policies defined by Federal and State Governments or by local non-governmental agencies such as the Chamber of Commerce and Tourism (CANACO), Hotel and Motel Association (AMHM- Ciudad Juarez) or the Chamber of Restaurants (CANIRAC) among others (GALLEGOS; LÓPEZ, 2004). As a result, most of the initiatives to encourage tourism and entertainment at the local level have lacked of continuity. This situation left the entertainment sector of Ciudad Juarez in a fragile position to become competitive regionally since it has barely been prepared to forecast opportunities or challenges for the local businesses. In addition, another relevant aspect that affects the competitiveness of the entertainment sector in Ciudad Juarez is the effectiveness of how governmental agencies resolve the local social problems and contributes to create an attractive business climate. To illustrate, in 2003, Ciudad Juarez became the city with the second highest average of expenditure per tourist (US\$59.7) among Northern Mexican Border cities and selected as an attractive place to visit for its accessibility, hospitality, food, beverages, and value of money. Notwithstanding, the local entertainment sector has been unable to take advantage of such strengths since foreign visitors had gradually reduced their visits to the Mexican side to avoid the corruption of local authorities and to be away from the local problems of public safety (BRINGAS, 2004).

Public safety has become the biggest barrier for local economic development in Mexico and has encouraged the migration of both businesses and consumers to other regions or countries. During the last 5 years, Ciudad Juarez has experienced a deep crisis in public safety. This social crisis, based on the war between Drug Cartels, has produced insecurity in everyday life and economic decline. It has been estimated that about 30,000 people have left the city and many businesses have closed down and relocated in El Paso (MacCORMACK, 2010). For today experience, it can be observed that night life activities have dramatically reduced in Ciudad Juarez and increased in El Paso. A similar situation is being observed in the restaurant industry, cultural and sport activities, cultural and sport practices and in the Hotel sector as well. The underlying factors need to be analyzed in order to understand the complex mechanism of local change. Empirical works are needed as a valuable basis for analysis. The first step is to undertake a student survey conducted within the largest local public University in the city. College Students were chosen to substantiate whether or not changes in geographic paths are occurring among 
display that $54 \%$ of the total sample population crosses to ELP searching for entertainment activities, mainly, those related with bars and restaurants. In this pattern, gender and age are two relevant factors to define whether crossing or not to ELP and whether attending or not to bars and restaurants. Attending to such results, and to the crisis in public safety experienced locally, it seems that the entertainment sector in Ciudad Juarez has lost its capacity to retain customers and that it is necessary to develop new strategies to recover competitiveness. These strategies might be relied more in public policies related to urban planning and urban management than in actions relate to the quality or prices of products and services. In Ciudad Juarez, the local entertainment sector must specialize in attracting and retaining young people. Based on the current social crisis such business must adapt itself to the circumstances and modified schedules of operation, and work together with the local government to implement urban management strategies to improve safety such as the promotion of entertainment districts with clustered business rather than allowing the establishment of isolated entertainment business all over the city.

\section{CONCLUSIONS AND PERSPECTIVES}

This research has taken College Students as a sample population to identify if local inhabitants in Ciudad Juarez are crossing the border into USA to enjoy entertainment activities. Although, it might be necessary to conduct a more comprehensive study to obtain further detailed evidence, the representativeness of the sample population has allowed the development of general considerations and conclusions about the current competitiveness of the local entertainment sector in Ciudad Juarez. Data results suggest that there exists a tendency among the young population to cross into the USA searching for entertainment since more than $50 \%$ of the overall sample population followed such pattern. This might be a consequence of the social crises experienced by Ciudad Juarez in terms of crime and insecurity. Particularly, considering that most of the entertainment activities conducted by the local population are related to alcohol consumption.

The analysis of governmental documents regarding the entertainment preferences of foreign visitors and the data results found by this study among College Students suggest that the two preferred entertainment activities, in Ciudad Juarez, are attending to restaurants and bars. Such tendency implies that the local population present very simple entertainment patterns and do not demand the diversification of this sector of activity. In other words, research results suggest that the difference in the level of education is not a factor when the people a researching for entertainment in Ciudad Juarez. This situation could be illustrated if it is considered that about $52 \%$ of the expenditure done by the low-educated foreign visitors is addressed to restaurants, bars and night clubs while the two main activities for entertainment chosen by College Students in Ciudad Juarez were attending to Bars and restaurants. Based on both indicators it could be argued that the differences in degree of education do not modify entertainment preferences among the local population. This explain why, according to the official Mexican System of Information 
for Businesses, almost one third of the total 4,753 businesses established in Ciudad Juarez until 2011 are, particularly, dedicated to services such as bars and restaurants. Further research should be dedicated to find out in what degree such dominant preferences for eating and drinking have constrained the development of cultural activities and the diversification of the entertainment sector along the Northern Mexican Border cities.

The current losing of customers experienced by the local entertainment businesses in Ciudad Juarez demands the development of imaginative schemes to recover the attractiveness and competitiveness of the local entertainment sector. To this respect, the historical legacy of the city could become an asset to exploit. This trend will require the development of a Comprehensive Strategic Plan for the Reactivation of the Local Entertainment Activity (REACT). This plan must target the following issues: First, the overcoming of the problem of public safety through urban management and zoning strategies. These should be areas that clustered entertainment businesses and that are dominated by pedestrian areas. Autos will not be allowed to enter into these areas. In addition, it must be necessary to pursue the reactivation of traditional entertainment areas that were successful before the public safety crisis and that have been closed. Tax Incentives for construction, properties, land-use licenses and others should be provided to local and foreign investors to activate the entertainment sector. Second, recover the European legacy and the Mexican Historical legacy of the city through an urban renewal strategy. This strategy should target the reactivation of historical neighborhoods and buildings that rescue the Paso del Norte thematic concept. As a complement, historical events that happened in the city should be promoted permanently to diversify the entertainment alternatives for foreign visitors. A third point must be the development of an Annual Cross-border Entertainment Agenda to promote the local history of the region. This effort might imply in providing joint transportation services and complement activities on both Ciudad Juarez and ELP, particularly, regarding complementary activities on restaurants, bars, night clubs and thematic entertainment. Finally, the establishment of a Bi-national Office for City Marketing both to diminish the negative social image of the region and to motivate foreign visitors to visit one of the ancient areas in North America. Marketing strategies should focus to remark the opportunity for foreign visitors to recreate the local ancient traditions of the region and to recover their confidence to search for entertainment on the Mexican side.

\section{REFERENCES}

ALVAREZ, J. Los elementos de la cultura mexicana y su relación con el turismo fronterizo en Ciudad Juárez. In: Haciael México que anhelamos: un acercamiento a sus realidades. México: Doble Hélice, 2009. p.143-163.

BANCO DE MÉXICO. La balanza de pagos en el primer trimestre del 2007. México: Banco de México, 2007.

BRINGAS, N. (Comp.). Turismo fronterizo: caracterización y posibilidades de desarrollo.Tijuana: Secretaría de Turismo / Centro de Estudios Superiores de Turismo, 2004. 
CHAPARRO, L. Vanguardia. Retrieved February, 20th2011. In: <http://www.vanguardia.com.mx/40_de_ restaurantes_en_juarez_han_cerrado_por_violencia-648800.html>. Acesso em: 01 dez. 2011.

GALLEGOS, O.; LÓPEZ, A. Turismo y estructura territorial en Ciudad Juárez. Boletín del Instituto de Geografía. México: UNAM,2004. p. 141-162.

GONZÁLEZ DE LA VARA, M. De provincia a frontera. Juárez, Chihuahua, México: UACJ/COLEF/ Colección Paso del Norte, 2002.

MacCORMACK, J. Cities in pain: for residents who have not fled, living on the border has turned into a nightmare. San Antonio Express News. March 2 ${ }^{\text {nd }} ., 2010$.

MÁRQUEZ, D. Balanza de pagos del 1er trimestre del 2007. México: Vector Económico, June 11 ${ }^{\text {th }}, 2007$.

LLERA, F.J ., LÓPEZ, M. A.;NESBITT, L. El Impacto del TLC en las políticas turísticas de la región fronteriza de Ciudad Juárez / El Paso. In: Dinámicas y tendencias del turismo contemporáneo. México: Universidad Autónoma de Ciudad Juárez, 2009. p. 437-445.

LLERA, F.;LÓPEZ, M. A. El idioma inglés como factor de competitividad de una ciudad fronteriza: el caso de Ciudad Juárez, México. Journal Annales, v. 20, n. 2, p. 507-512, 2010.

MARTÍNEZ, O. J. Border boom town: ciudad Juarez since 1848. Austin, Texas, USA: University of Texas Press,1978.

OTERO, S. Desde 2007, 10 mil negocios han cerrado en Juárez. El Universal. México: February, 2010. p. 12. PEÑA, S. Comercio transfronterizo y su impacto en la región de El Paso-Ciudad Juárez. Frontera Norte, v. 15, n.29, January - June, 2003. p. 185-200.

PÉREZ, D. Historias cercanas (relatos ignorados de la frontera). Chihuahua: Solar Colección, 2004.

TURNER, E. Influencia de la industria maquiladora y el TLCAN en la demografía y el desarrollo de la frontera norte de México. Análisis económico, v. 21, n.46,First quarter, 2006. p. 369-396.

Recebido em 13/04/2012.

Aceito para publicação em 20/05/2012. 